\title{
Determinan yang Berpengaruh pada Minat Investasi di Pasar Modal
}

\author{
Luh Putu Sita Dewi ${ }^{1}$ \\ Fakultas Ekonomi dan Bisnis \\ Universitas Udayana, Indonesia
}

\author{
Gayatri $^{2}$ \\ Fakultas Ekonomi dan Bisnis \\ Universitas Udayana, Indonesia
}

\begin{abstract}
Surel : sitadewi28@gmail.com
ABSTRAK

Investasi di pasar modal merupakan alternatif bagi masyarakat yang ingin menginvestasikan kelebihan dana yang dimiliki sekaligus dapat menjadi penggerak perekonomian di suatu negara. Penelitian ini bertujuan untuk memperoleh bukti empiris mengenai determinan yang mempengaruhi minat investasi di pasar modal. Penentuan sampel pada penelitian ini menggunakan metode purposive sampling dengan sampel sebanyak 105 mahasiswa yang sudah menempuh mata kuliah teori pasar modal dan telah memiliki rekening efek. Teknik analisis data pada penelitian ini menggunakan analisis regresi linear berganda. Hasil penelitian menyatakan bahwa pemahaman investasi, motivasi, dan bandwagon effect berpengaruh positif pada minat investasi di pasar modal. Hal ini berarti semakin tinggi pemahaman investasi, motivasi, serta fenomena bandwagon effect yang terjadi, maka minat investasi di pasar modal juga akan semakin tinggi.
\end{abstract}

Kata Kunci: $\quad$ Minat Investasi; Pemahaman Investasi; Motivasi; Bandwagon Effect.

\section{Determinants Affecting The Interests of Investment in Capital Market}

\begin{abstract}
Investing in the capital market is an alternative for people who want to invest their excess funds as well as being able to drive the economy in a country. This study aims to obtain empirical evidence regarding the determinants that influence investment interest in the capital market. Determination of the sample in this study using purposive sampling method with a sample of 105 students who have taken the capital market theory course and already have an account of effects. The data analysis technique used is multiple linear regression analysis. The results of the study indicate that investment understanding, motivation, and the bandwagon effect have a positive effect on investment interest in the capital market. This means that the higher the understanding of investment, motivation, and the bandwagon effect phenomenon that occurs, the higher the interest in investing in the capital market.
\end{abstract}

Keywords: Investing Interest; Investment Understanding; Motivation; Bandwagon Effect.

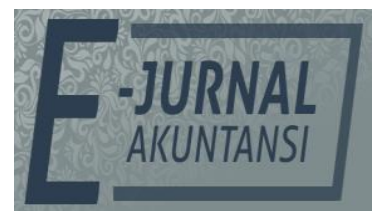

e-ISSN 2302-8556

Vol. 31 No. 5

Denpasar, Mei 2021

Hal. 1082-1096

DOI:

10.24843/EJA.2021.v31.i05.p02

PENGUTIPAN:

Dewi, L.P.S., \& Gayatri. (2021). Determinan yang Berpengaruh pada Minat Investasi di Pasar Modal. EJurnal Akuntansi, 31(5), 1082-

1096

RIWAYAT ARTIKEL: Artikel Masuk: 12 November 2020 Artikel Diterima: 19 Februari 2021

Artikel dapat diakses : https://ojs.unud.ac.id/index.php/Akuntansi/index 


\section{PENDAHULUAN}

Investasi adalah komitmen untuk menggunakan sebagian dana dengan harapan memperoleh keuntungan di masa depan (Wibowo \& Purwohandoko, 2019). Pada kehidupan masyarakat saat ini, investasi dipandang memiliki dua paradigma, yaitu sebagai kebutuhan dan keinginan (Tandio \& Widanaputra, 2016). Investasi dipandang sebagai kebutuhan apabila ketika individu mempunyai dana berlebih, maka dana itu akan dialokasikan ke instrumen investasi. Sebaliknya, jika individu memandang investasi sebagai keinginan, maka saat mempunyai dana berlebih, ia akan memilih untuk mengalokasikan dana pada tabungan bukan pada instrumen investasi. Berdasarkan hasil riset dari lembaga riset pemasaran, Inside ID, tahun 2018, responden rata-rata mengalokasikan pendapatannya sebesar 13\% untuk investasi dan tabungan (kontan.co.id, 2018). Dari alokasi tersebut, sepuluh persen pendapatan dialokasikan ke tabungan dan tiga persen dialokasikan ke investasi. Hal ini menunjukkan bahwa masyarakat Indonesia lebih tertarik untuk menempatkan dana ke tabungan karena risikonya cenderung lebih kecil dibandingkan investasi. Tak hanya pada aset tetap, investasi juga dapat dilakukan pada instrumen keuangan di pasar modal, baik itu saham, obligasi, reksadana, atau efek derivatif lainnya (Awais et al., 2016). Gurusamy \& Santhiyavani (2019) menyatakan bahwa investor pasar modal mampu menjadi penggerak perekonomian suatu negara.

Berdasarkan Single Investor Identification (SID), persentase jumlah investor pasar modal di Indonesia per akhir Maret 2020 hanya sebesar satu persen dari seluruh jumlah penduduk Indonesia (tempo.co, 2020). Apabila dibandingkan dengan negara Malaysia dan Singapura, persentase jumlah investor pasar modal Indonesia terbilang sangat kecil, dimana pada tahun 2017, persentase jumlah investor pasar modal di Malaysia sudah mencapai angka 12,8 persen, dan di Singapura mencapai angka 30 persen (KumparanNews, 2017). Persentase jumlah investor pasar modal di Provinsi Bali, berdasarkan data per Februari 2020 hanya sebesar 0,54 persen dari jumlah penduduk Provinsi Bali (Bisnis Bali, 2020). Berdasarkan survei yang penulis lakukan pada mahasiswa aktif Program Studi S1 Akuntansi angkatan 2017 Fakultas Ekonomi dan Bisnis Universitas Udayana yang berjumlah 289 mahasiswa, hasilnya adalah hanya sebesar 36,33 persen mahasiswa yang telah memiliki rekening efek di pasar modal, sedangkan sisanya sebesar 63,67 persen belum memiliki rekening efek di pasar modal.

Guna meningkatkan minat investasi masyarakat, Bursa Efek Indonesia (BEI) mengadakan kampanye Yuk Nabung Saham yang diharapkan dapat mengubah karakter masyarakat di Indonesia dari yang semula saving society menjadi investing society (Adiguna, 2018). Sejalan dengan kampanye tersebut, perguruan tinggi juga ikut andil dalam mengupayakan harapan dari BEI yakni dengan memberikan pemahaman investasi melalui penerapan mata kuliah yang berkaitan dengan pasar modal dan analisis informasi keuangan. Pemahaman investasi yang meliputi pemahaman tentang gambaran umum pasar modal dan pemahaman tentang analisis informasi keuangan merupakan hal penting untuk dimiliki oleh calon investor. Nisa \& Zulaika (2017) menyatakan bahwa saat ini calon investor tidak hanya mempertimbangkan pengetahuan umum tentang pasar modal sebelum berinvestasi, tetapi juga mempertimbangkan faktor-faktor lain seperti accounting information serta self image perusahaan. Pemahaman atas 
informasi yang terkandung dalam laporan keuangan dapat membantu seseorang untuk membuat keputusan yang tepat saat akan menginvestasikan dana demi kesejahteraannya (Nalini et al., 2016). Guna mengetahui informasi yang terkandung dalam laporan keuangan, calon investor biasanya menggunakan rasio-rasio keuangan seperti Earning Per Share (EPS), Return on Asset (ROA), Return on Equity (ROE), Debt to Earning Ratio (DER), dan Price to Book Value (PBV) (Jannah \& Ady, 2017). Hal ini berarti pemahaman investasi yang tidak hanya berupa pemahaman atas gambaran umum investasi tetapi juga pemahaman atas informasi keuangan suatu perusahaan akan mampu mempengaruhi investor untuk berinvestasi (Abdeldayem, 2016). Theory of planned behavior menyatakan bahwa kegiatan belajar dalam kaitannya dengan pemahaman investasi dapat menumbuhkan intensi yang dapat mempengaruhi tingkah laku (Ajzen, 1991). Theory of planned behavior banyak digunakan pada penelitian perilaku konsumen sebagai pendekatan dalam memprediksi niat serta perilaku (Simon, 2016). Teori ini didasarkan pada asumsi bahwa manusia adalah makhluk rasional dan akan berperilaku dengan cara yang sadar serta mempertimbangkan segala informasi yang ada (Gayatri, 2020:213).

Penelitian sebelumnya oleh Wibowo \& Purwohandoko (2019) menyatakan, semakin tinggi pemahaman individu atas investasi, maka semakin tinggi pula tingkat ketertarikan akan melakukan investasi. Penelitian yang dilakukan oleh (Lubis, 2019) pada mahasiswa Universitas Negeri Medan menyatakan bahwa pengetahuan investasi berpengaruh positif terhadap minat berinvestasi di pasar modal. Penelitian oleh Maulana \& Kaukab (2020) menyatakan bahwa pengetahuan investasi memiliki pengaruh positif pada minat investasi saham di pasar modal. Agestina et al. (2020) dalam penelitiannya menyatakan bahwa pemahaman investasi berpengaruh positif signifikan pada minat investasi mahasiswa. Berdasarkan pada hasil penelitian tersebut maka diperoleh hipotesis sebagai berikut.

$\mathrm{H}_{1}$ : Pemahaman investasi memiliki pengaruh positif pada minat investasi di pasar modal.

Motivasi yang tinggi dalam diri seseorang juga diduga berpengaruh pada minat seseorang untuk berinvestasi di pasar modal. Berdasarkan teori hierarki kebutuhan (Maslow, 1943), terdapat lima kebutuhan dalam diri seseorang, yaitu kebutuhan fisiologis, kebutuhan keamanan, kebutuhan sosial, kebutuhan penghargaan, dan kebutuhan aktualisasi diri. Umumnya, ketika seseorang telah merasa kebutuhan substansialnya tercukupi, maka akan timbul kebutuhan berikutnya yang ingin dicapai, salah satunya dapat berupa kebutuhan berinvestasi. Jika investasi dianggap sebagai suatu kebutuhan yang harus dicapai, maka akan timbul motivasi berupa semangat untuk mencari informasi tentang investasi dan mencoba mempraktikkannya. Motivasi merupakan proses ketika individu mengenal kebutuhannya kemudian mengambil tindakan untuk memuaskan kebutuhan tersebut (Malik, 2017). Motivasi sangat bergantung pada konsekuensi positif yang diharapkan terjadi ketika melakukan suatu tindakan (Schunk \& Dibenedetto, 2020). Tingginya motivasi seseorang akan dapat mempengaruhi minatnya dalam berinvestasi.

Hasil penelitian terdahulu oleh Riyadi (2017) menunjukkan bahwa motivasi memiliki pengaruh terhadap minat investasi di pasar modal. Penelitian 
oleh Saputra (2018) juga mendapatkan hasil bahwa motivasi memiliki pengaruh yang positif dan signifikan terhadap minat investasi pada mahasiswa STIE Balikpapan. Hasil yang sama juga terjadi pada penelitian oleh Darmawan \& Japar (2020) yaitu motivasi memiliki pengaruh positif dan signifikan pada minat investasi saham di pasar modal syariah. Berdasarkan pada temuan-temuan tersebut, maka dapat ditarik hipotesis sebagai berikut.

$\mathrm{H}_{2}$ : Motivasi memiliki pengaruh positif pada minat investasi di pasar modal.

Minat investasi di pasar modal juga dapat timbul akibat adanya faktor lingkungan dan teman sebaya. Seseorang memiliki kecenderungan untuk mempercayai atau melakukan sesuatu karena teman sebayanya atau mayoritas orang mempercayai atau melakukan hal itu, peristiwa semacam ini sering disebut dengan bandwagon effect (Hasanah et al., 2019). Banerji et al. (2020) menyatakan, bandwagon effect adalah fenomena sosial dimana seseorang dipengaruhi untuk membuat keputusan karena orang lain di lingkungannya melakukan hal itu. Semakin banyak orang yang melakukan hal tersebut, semakin besar kemungkinan orang lain untuk mengikutinya. Fenomena ini sering muncul di dunia investasi, dimana investor akan meniru tindakan investor lainnya meskipun memiliki pengetahuan yang kurang dan informasi yang terbatas (Sabir et al., 2019). Pada dasarnya, bandwagon effect termasuk bagian dari bias kognitif yang dialami oleh banyak orang, dimana bias kognitif merupakan suatu pemikiran yang dipengaruhi akibat sesuatu tersebut dilakukan oleh orang banyak (Cherry, 2020). Bias kognitif memiliki dampak signifikan terhadap perilaku investor (Kumar \& Goyal, 2016). Fenomena bandwagon effect sesuai dengan teori psikologi massa yang diangkat ke ranah akademik oleh seorang psikolog Gustave Le Bon dalam bukunya yang berjudul "Crowd Psychology" (Mudzakkir, 2019). Le Bon (1895:33) menyatakan bahwa massa memiliki pendirian yang mudah goyah dan berubah. Teori psikologi massa menyatakan bahwa masyarakat akan cenderung beranggapan bahwa apapun yang dilakukan oleh orang kebanyakan akan dianggap bagus, perihal kebenarannya akan dipertimbangkan berdasarkan jumlah massa. Jadi, pengaruh aksi massa akan lebih besar sehingga menurunkan pengaruh alasan individu dalam menentukan suatu keputusan (Stolwijk et al., 2016).

Menurut penelitian Hasanah et al. (2019), bandwagon effect terbukti memiliki pengaruh terhadap minat investasi mahasiswa. Mahasiswa cenderung memiliki minat yang besar untuk berinvestasi ketika teman-temannya melakukan hal yang sama. Penelitian oleh Hati \& Windy (2019) menyatakan, kecenderungan efek bandwagon atau efek ikut-ikutan teman berpengaruh namun tidak terlalu kuat pada minat berinvestasi di pasar modal. Atas dasar hasil temuan tersebut, maka dapat ditarik hipotesis sebagai berikut.

$\mathrm{H}_{3}$ : Bandwagon effect memiliki pengaruh positif pada minat investasi di pasar modal.

\section{METODE PENELITIAN}

Penelitian ini menggunakan pendekatan kuantitatif berbentuk asosiatif kausal. Populasi yang digunakan adalah seluruh mahasiswa angkatan 2017 Program Studi S1 Akuntansi Fakultas Ekonomi dan Bisnis Universitas Udayana. Penentuan sampel menggunakan metode non probability sampling yaitu pusposive 
sampling dengan kriteria mahasiswa yang telah menempuh mata kuliah teori pasar modal dan telah memiliki rekening efek di pasar modal, sehingga sampel pada penelitian ini berjumlah 105 mahasiswa. Metode pengumpulan data dilakukan dengan menyebarkan kuesioner online berupa formulir Google kepada responden.

Obyek penelitian ini adalah minat investasi di pasar modal. Minat investasi di pasar modal dapat diartikan sebagai keinginan seseorang untuk mempelajari segala hal yang berkaitan dengan investasi dan memicunya untuk berinvestasi. Indikator minat investasi antara lain : (1) kemauan untuk mencari tahu mengenai instrumen-instrumen investasi, (2) kemauan untuk meluangkan waktu mengikuti seminar dan pelatihan investasi, (3) mencoba berinvestasi. Alat ukur yang digunakan untuk mengukur variabel minat investasi di pasar modal adalah skala likert modifikasi.

Faktor pertama yang diduga berpengaruh pada minat investasi di pasar modal adalah pemahaman investasi. Pemahaman investasi adalah kemampuan untuk memahami investasi, tidak hanya memahami gambaran umum investasi, tetapi juga memahami informasi yang terkandung dalam laporan keuangan suatu perusahaan. Indikator pemahaman investasi antara lain : (1) pemahaman tentang cara investasi di pasar modal, (2) pemahaman tentang jenis instrumen investasi, (3) pemahaman tentang tingkat pengembalian investasi, (4) pemahaman tentang tingkat risiko investasi, (5) pemahaman tentang perhitungan EPS, ROA, ROE, DER, PBV. Alat ukur yang digunakan untuk mengukur variabel pemahaman investasi adalah skala likert modifikasi.

Faktor kedua yang diduga berpengaruh pada minat investasi di pasar modal adalah motivasi. Motivasi adalah proses pemberian daya penggerak yang mampu menciptakan gairah seseorang dalam melakukan sesuatu dan terintegrasi dengan segala upaya untuk dapat mencapai kepuasan (Hasibuan, 2016:111). Indikator motivasi antara lain : (1) motivasi dimulai dari adanya perubahan energi dalam diri seseorang, (2) motivasi ditandai dengan munculnya perasaan yang mengarahkan tingkah laku, (3) motivasi ditandai dengan reaksireaksi dalam rangka pencapaian tujuan. Alat ukur yang digunakan untuk mengukur variabel motivasi adalah dengan menggunakan skala likert modifikasi.

Fenomena bandwagon effect juga diduga mempengaruhi minat seseorang untuk berinvestasi di pasar modal. Bandwagon effect adalah fenomena dimana seseorang akan melakukan sesuatu hal karena melihat fakta bahwa orang lain juga melakukannya (Niesiobedzka, 2018) . Dalam dunia investasi, bandwagon effect dapat diartikan sebagai fenomena psikologis yang ditandai dengan investor yang mulai bergantung pada keputusan orang lain terlepas dari bukti yang mendasarinya (Zakirullah \& Rahmawati, 2020). Indikator bandwagon effect antara lain : (1) tingkat keinginan berinvestasi dikarenakan lingkungan keluarga dan teman, (2) tingkat keinginan berinvestasi dikarenakan dorongan dari dosen, keluarga, dan teman. Alat ukur yang digunakan untuk mengukur variabel ini adalah skala likert modifikasi.

Uji validitas dan uji reliabilitas digunakan untuk menguji instrumen pada penelitian ini. Uji validitas dilakukan dengan mengkorelasikan antara skor faktor dengan skor total, jika koefisien korelasi tiap faktor positif 0,3 ke atas maka 
kuesioner tersebut dinyatakan valid. Uji reliabilitas bertujuan untuk menguji konsistensi jawaban responden. Instrumen dapat dikatakan reliabel jika mampu menghasilkan data yang sama ketika digunakan berulang kali (Sugiyono, 2017:130). Apabila nilai Croncbach's Alpha lebih dari 0,6 maka instrumen dapat dikatakan reliabel.

Teknik analisis data pada penelitian ini menggunakan analisis regresi linear berganda dengan bantuan software SPSS 23 for Windows, dimana sebelum itu akan dilakukan uji statistik deskriptif serta uji asumsi klasik terlebih dahulu. Uji statistik deskriptif bertujuan untuk dapat memberikan deskripsi atas data, dilihat dari nilai rata-rata, standar deviasi, serta maksimum-minimum (Ghozali, 2016:150). Uji asumsi klasik meliputi uji normalitas, uji multikolinearitas, dan uji heteroskedastisitas. Analisis regresi linear berganda digunakan untuk mengetahui hubungan secara linear antara variabel independen dengan variabel dependen. Model persamaan analisis regresi linear berganda yaitu (Sugiyono, 2017:261).

$Y=\alpha+\beta_{1} X_{1}+\beta_{2} X_{2}+\beta_{3} X_{3}+\varepsilon$

Keterangan :

\begin{tabular}{|c|c|}
\hline $\mathrm{Y}$ & $=$ Minat Investasi di Pasar Modal \\
\hline a & $=$ Konstanta \\
\hline$\beta_{1}, \beta_{2}, \beta_{3}$ & $=$ Koefisien Regresi \\
\hline$x_{1}$ & $=$ Pemahaman Investasi \\
\hline$X_{2}$ & $=$ Motivasi \\
\hline & $=$ Bandwagon Effect \\
\hline & $=$ Error term (variabel pengganggu) \\
\hline
\end{tabular}

Uji $\mathrm{R}^{2}$ dilakukan guna mengukur kemampuan model regresi dalam menerangkan variabel dependen. Jika nilai $\mathrm{R}^{2}$ mendekati satu, berarti variabel independen berisi hampir seluruh informasi yang diperlukan untuk memprediksi variabel dependennya. Koefisien determinasi dapat dilihat dari nilai adjusted $\mathrm{R}^{2}$ dalam tabel Model Summary (Ghozali, 2016:95).

Uji $\mathrm{F}$ bertujuan untuk mengetahui kelayakan model pada penelitian sebagai alat analisis untuk menguji pengaruh simultan variabel independen pada variabel dependennya. Uji $\mathrm{F}$ dilakukan dengan melihat nilai signifikansi pada tabel annova dalam SPSS. Jika signifikansi annova kurang dari 0,05, maka variabel independen secara signifikan mempengaruhi variabel dependen (Ghozali, 2016:96).

Uji t dilakukan untuk menguji sejauh mana pengaruh variabel independen secara parsial dapat menerangkan variasi variabel dependen (Ghozali, 2016:97). Jika nilai signifikansi t lebih kecil dari 0,05, maka variabel independen dianggap berpengaruh secara parsial terhadap variabel dependen.

\section{HASIL DAN PEMBAHASAN}

Uji instrumen penelitian terdiri dari uji validitas dan uji reliabilitas. Untuk memenuhi syarat validitas, koefisien korelasi tiap faktor harus $>0,3$. Pada uji validitas ini, peneliti menggunakan 30 kuesioner yang disebarkan kepada responden sebenarnya. Hasil uji validitas tersaji dalam Tabel 1.

Tabel 1, menunjukkan bahwa setiap pernyataan kuesioner pada keempat variabel penelitian yang ada, yaitu minat investasi di pasar modal, pemahaman 
investasi, motivasi, serta bandwagon effect, seluruhnya memiliki nilai koefisien korelasi lebih besar dari 0,30, hal ini berarti pernyataan yang ada pada kuesioner bersifat valid.

Tabel 1. Hasil Uji Validitas

\begin{tabular}{|c|c|c|}
\hline Variabel & Indikator & Koefisien Korelasi \\
\hline \multirow[t]{8}{*}{ Minat Investasi } & $\mathrm{Y}_{.1}$ & 0,616 \\
\hline & Y.2 & 0,768 \\
\hline & Y.3 & 0,654 \\
\hline & Y.4 & 0,805 \\
\hline & Y.5 & 0,845 \\
\hline & Y.6 & 0,644 \\
\hline & Y.7 & 0,838 \\
\hline & Y.8 & 0,881 \\
\hline \multirow[t]{11}{*}{ Pemahaman Investasi } & $\mathrm{X}_{1.1}$ & 0,730 \\
\hline & $\mathrm{X}_{1.2}$ & 0,828 \\
\hline & $\mathrm{X}_{1.3}$ & 0,682 \\
\hline & $\mathrm{X}_{1.4}$ & 0,654 \\
\hline & $\mathrm{X}_{1.5}$ & 0,574 \\
\hline & $\mathrm{X}_{1.6}$ & 0,731 \\
\hline & $\mathrm{X}_{1.7}$ & 0,871 \\
\hline & $\mathrm{X}_{1.8}$ & 0,853 \\
\hline & $\mathrm{X}_{1.9}$ & 0,899 \\
\hline & $\mathrm{X}_{1.10}$ & 0,899 \\
\hline & $\mathrm{X}_{1.11}$ & 0,860 \\
\hline \multirow[t]{6}{*}{ Motivasi } & $\mathrm{X}_{2.1}$ & 0,857 \\
\hline & $\mathrm{X}_{2.2}$ & 0,837 \\
\hline & $\mathrm{X}_{2.3}$ & 0,679 \\
\hline & $\mathrm{X}_{2.4}$ & 0,800 \\
\hline & $\mathrm{X}_{2.5}$ & 0,810 \\
\hline & $\mathrm{X}_{2.6}$ & 0,718 \\
\hline \multirow[t]{5}{*}{ Bandwagon Effect } & $X_{3.1}$ & 0,721 \\
\hline & $X_{3.2}$ & 0,501 \\
\hline & $X_{3.3}$ & 0,591 \\
\hline & $\mathrm{X}_{3.4}$ & 0,675 \\
\hline & $\mathrm{X}_{3.5}$ & 0,649 \\
\hline
\end{tabular}

Sumber : Data Penelitian, 2020

Uji instrumen kedua yang perlu dilakukan selain uji validitas, ialah uji reliabilitas. Suatu instrumen dapat dikatakan bersifat reliabel apabila memiliki nilai Cronbach's Alpha lebih dari 0,60. Adapun hasil uji reliabilitas dalam penelitian ini tersaji dalam Tabel 2, berikut ini.

\section{Tabel 2. Hasil Uji Reliabilitas}

\begin{tabular}{lc}
\hline \multicolumn{1}{c}{ Variabel } & Nilai Cronbach's Alpha \\
\hline Minat Investasi di Pasar Modal & 0,886 \\
Pemahaman Investasi & 0,936 \\
Motivasi & 0,862 \\
Bandwagon Effect & 0,619 \\
\hline
\end{tabular}

Sumber : Data Penelitian, 2020 
Tabel 2, menunjukkan nilai cronbach's alpha pada setiap instrumen penelitian $>0,60$, jadi pernyataan kuesioner bersifat andal/reliabel.

Uji statistik deskriptif digunakan untuk memberi gambaran atas suatu data yang dilihat dari jumlah sampel, nilai minimum, nilai maksimum, nilai ratarata, serta standar deviasi pada masing-masing variabel dalam penelitian. Hasil uji statistik deskriptif tersaji dalam Tabel 3, berikut ini.

Tabel 3. Hasil Uji Statistik Deskriptif

\begin{tabular}{lccccc}
\hline \multicolumn{1}{c}{ Variabel } & $\mathrm{N}$ & Minimum & Maximum & Mean & $\begin{array}{c}\text { Std. } \\
\text { Deviation }\end{array}$ \\
\hline $\begin{array}{l}\text { Minat Investasi di } \\
\text { Pasar Modal }\end{array}$ & 105 & 18 & 32 & 27,31 & 3,622 \\
$\begin{array}{l}\text { Pemahaman } \\
\text { Investasi }\end{array}$ & 105 & 24 & 44 & 36,10 & 5,629 \\
$\begin{array}{l}\text { Motivasi } \\
\text { Bandwagon Effect }\end{array}$ & 105 & 13 & 24 & 19,90 & 3,053 \\
\hline
\end{tabular}

Sumber: Data Penelitian, 2020

Tabel 3, menunjukkan bahwa minat investasi di pasar modal (Y) memiliki nilai rata-rata sebesar 27,31 dengan nilai minimum sebesar 18 serta nilai maksimum sebesar 32. Nilai rata-rata sebesar 27,31 memiliki kecenderungan mendekati nilai maksimum yaitu 32. Hal ini menunjukkan bahwa mahasiswa memiliki minat investasi di pasar modal yang cenderung tinggi. Nilai standar deviasi pada variabel ini sebesar 3,622, hal ini berarti terjadi penyimpangan sebesar 3,622.

Pemahaman investasi memiliki nilai rata-rata sebesar 36,10 dengan nilai maksimum sebesar 44 serta nilai minimum sebesar 24 . Nilai rata-rata 36,10 cenderung mendekati nilai maksimum yaitu 44 . Hal ini menunjukkan bahwa pemahaman investasi yang dimiliki mahasiswa cenderung tinggi. Nilai standar deviasi pada variabel ini sebesar 5,629, hal ini berarti terjadi penyimpangan sebesar 5,629.

Motivasi memiliki nilai rata-rata sebesar 19,90 dengan nilai maksimum sebesar 24 dan nilai minimum sebesar 13. Nilai rata-rata 19,90 cenderung mendekati maksimum yaitu 24. Hal ini menunjukkan bahwa motivasi yang dimiliki mahasiswa cenderung tinggi. Nilai standar deviasi pada variabel ini sebesar 3,053, hal ini berarti terjadi penyimpangan sebesar 3,053.

Bandwagon effect memiliki nilai rata-rata sebesar 14,44 dengan nilai maksimum sebesar 20 dan nilai minimum sebesar 8 . Nilai rata-rata sebesar 14,44 cenderung mendekati maksimum yaitu 20. Hal ini menunjukkan bahwa terjadi fenomena bandwagon effect yang cenderung tinggi pada mahasiswa. Nilai standar deviasi pada variabel ini sebesar 2,993, hal ini berarti terjadi penyimpangan sebesar 2,993.

Uji asumsi klasik yang pertama adalah uji normalitas. Untuk mendeteksi normalitas data, digunakan Kolmogorov-Smirnov Test dengan kriteria jika Assymp.Sig (2-tailed) lebih besar dari level of significant yaitu 5 persen $(0,05)$, berarti data memiliki distribusi normal. Hasil uji normalitas tersaji dalam Tabel 4.

Tabel 4, menyajikan nilai signifikansi sebesar 0,200. Nilai 0,200 lebih besar dari level of significant yaitu 5 persen $(0,05)$, artinya model regresi berdistribusi normal. 
Tabel 4. Hasil Uji Normalitas

\begin{tabular}{lc}
\hline & Unstandardized Residual \\
\hline $\mathrm{N}$ & 105 \\
Kolmogorov-Smirnov Test & 0,051 \\
Asymp. Sig (2-tailed) & 0,200 \\
\hline
\end{tabular}

Sumber: Data Penelitian, 2020

Uji multikolinearitas digunakan untuk menguji apakah terdapat hubungan antar variabel bebas dalam model regresi (Ghozali, 2016:103). Apabila nilai tolerance lebih dari 0,1 atau nilai VIF dibawah 10, maka model regresi terbebas dari gejala multikolinearitas. Hasil uji multikolinearitas tersaji pada Tabel 5, berikut ini.

Tabel 5. Hasil Uji Multikolinearitas

\begin{tabular}{lcc}
\hline \multicolumn{1}{c}{ Variabel } & \multicolumn{2}{c}{ Collinearity Statistic } \\
\cline { 2 - 3 } & Tolerance & VIF \\
\hline Pemahaman Investasi $\left(X_{1}\right)$ & 0,616 & 1,623 \\
Motivasi $\left(X_{2}\right)$ & 0,545 & 1,835 \\
Bandwagon Effect $\left(X_{3}\right)$ & 0,805 & 1,242 \\
\hline
\end{tabular}

Sumber : Data Penelitian, 2020

Tabel 5, menunjukkan bahwa ketiga variabel memiliki nilai tolerance masing-masing 0,$616 ; 0,545 ; 0,805$ dan nilai VIF masing-masing 1,$623 ; 1,835$; 1,242. Ketiga variabel tersebut memiliki nilai tolerance lebih besar dari 0,1 dan VIF kurang dari 10. Hal ini berarti pada ketiga variabel bebas tersebut tidak terjadi gejala multikolinearitas.

Uji heteroskedastisitas bertujuan untuk menguji apakah dalam regresi terjadi ketidaksamaan varians dari residual satu pengamatan ke pengamatan yang lain. Jika nilai signifikansinya lebih besar dari 0,05 berarti tidak terdapat gejala heteroskedastisitas. Hasil uji heteroskedastisitas tersaji pada Tabel 6, berikut ini.

Tabel 6. Hasil Uji Heteroskedastisitas

\begin{tabular}{lc}
\hline \multicolumn{1}{c}{ Variabel } & Sig. \\
\hline Pemahaman Investasi $\left(\mathrm{X}_{1}\right)$ & 0,186 \\
Motivasi $\left(\mathrm{X}_{2}\right)$ & 0,515 \\
Bandwagon Effect $\left(\mathrm{X}_{3}\right)$ & 0,546 \\
\hline
\end{tabular}

Sumber : Data Penelitian, 2020

Tabel 6, menunjukkan bahwa ketiga variabel bebas memiliki nilai signifikansi lebih besar dari 0,05. Hal ini berarti bahwa pada seluruh variabel bebas yang terdapat dalam model regresi, tidak mengandung gejala heteroskedastisitas.

Hasil analisis regresi linear berganda yang diolah dengan bantuan SPSS tersaji pada Tabel 7.

Berdasarkan pada Tabel 7, nilai konstanta (a) sebesar 6,141 memiliki arti, jika nilai pemahaman investasi $\left(X_{1}\right)$, motivasi $\left(X_{2}\right)$, dan bandwagon effect $\left(X_{3}\right)$ dianggap konstan pada nilai nol, maka nilai minat investasi di pasar modal $(Y)$ adalah sebesar 6,141. Koefisien dari ketiga variabel bebas bernilai positif, maka ketiga variabel bebas tersebut berpengaruh positif terhadap minat investasi di pasar modal. Persamaan regresinya adalah sebagai berikut.

$$
\mathrm{Y}=6,141+0,198 \mathrm{X}_{1}+0,547 \mathrm{X}_{2}+0,216 \mathrm{X}_{3}+\varepsilon
$$


Nilai dari Adjusted $R^{2}$ sebesar 0,609. Hal ini berarti sebesar 60,9 persen variansi minat investasi di pasar modal dipengaruhi oleh variansi pemahaman investasi, motivasi, dan bandwagon effect, sedangkan sisanya sebesar 39,1 persen dipengaruhi oleh faktor lain.

Tabel 7. Hasil Analisis Regresi Linear Berganda

\begin{tabular}{lccccc}
\hline \multirow{2}{*}{ Model } & \multicolumn{2}{c}{$\begin{array}{c}\text { Unstandardized } \\
\text { Coefficients }\end{array}$} & $\begin{array}{c}\text { Standardized } \\
\text { Coefficients }\end{array}$ & $\mathrm{t}$ & Sig. \\
\cline { 2 - 4 } & $\mathrm{B}$ & Std. Error & Beta & & \\
\hline 1 (Constant) & 6,141 & 1,678 & & 3,666 & 0,000 \\
Pemahaman Investasi & 0,198 & 0,050 & 0,308 & 3,947 & 0,000 \\
Motivasi & 0,547 & 0,099 & 0,461 & 5,558 & 0,000 \\
Bandwagon Effect & 0,216 & 0,083 & 0,178 & 2,612 & 0,010
\end{tabular}

Variabel Dependen : Minat Investasi di Pasar Modal

R Square $\quad: 0,621$

Adjusted R Square : 0,609

F Statistik : :55,102

Signifikansi $\quad: 0,000$

Sumber : Data Penelitian, 2020

Hasil uji F menunjukkan nilai signifikansi $0,000<0,05$. Hal ini berarti variabel pemahaman investasi, motivasi, dan bandwagon effect secara serempak berpengaruh terhadap minat investasi di pasar modal.

Hasil uji $\mathrm{t}$ menyatakan bahwa pemahaman investasi memiliki nilai $t_{\text {hitung }}$ sebesar 3,947 dengan signifikansi 0,000 < 0,05, maka $\mathrm{H}_{1}$ diterima. Motivasi

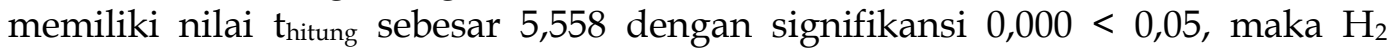
diterima. Bandwagon effect memiliki nilai thitung sebesar 2,612 dengan signifikansi 0,010 < 0,05, maka $\mathrm{H}_{3}$ diterima.

$\mathrm{H}_{1}$ menyatakan bahwa pemahaman investasi memiliki pengaruh positif pada minat investasi di pasar modal. Penelitian ini menunjukkan hasil bahwa pemahaman investasi memiliki nilai koefisien regresi sebesar 0,198 dengan nilai signifikansi $0,000<a(0,05)$, ini berarti variabel pemahaman investasi berpengaruh positif dan signifikan pada minat investasi di pasar modal. Jadi hipotesis pertama diterima. Semakin tinggi tingkat pemahaman investasi yang dimiliki oleh mahasiswa, maka minatnya untuk melakukan kegiatan investasi di pasar modal juga akan semakin tinggi. Rata-rata jawaban kuesioner menunjukkan bahwa mahasiswa menjawab setuju pada setiap pernyataan kuesioner. Hal tersebut mengindikasikan bahwa mahasiswa akan mempertimbangkan pemahaman investasi yang dimilikinya yang meliputi pemahaman atas gambaran umum investasi di pasar modal (seperti jenis-jenis investasi, tingkat pengembalian, dan risiko investasi) dan pemahaman atas analisis informasi keuangan suatu perusahaan seperti EPS, ROA, ROE, DER, dan PBV, sebelum berinvestasi di pasar modal. Ketika mahasiswa telah memiliki pemahaman investasi yang mumpuni, maka akan timbul ketertarikan untuk berinvestasi. Hasil penelitian ini konsisten dengan hasil penelitian sebelumnya oleh Wibowo \& Purwohandoko (2019), Lubis (2019), Maulana \& Kaukab (2020), dan Agustina et al. (2020) yang menyatakan bahwa pemahaman investasi memiliki pengaruh positif pada minat investasi. Sesuai dengan isi dari theory of planned behavior, kegiatan belajar dapat berdampak pada perubahan sikap dan 
tingkah laku yang merupakan hasil dari pengalaman individu dalam interaksi di lingkungan yang menyangkut kognitif, afektif, serta psikomotrik.

$\mathrm{H}_{2}$ menyatakan bahwa motivasi memiliki pengaruh positif pada minat investasi di pasar modal. Hasil penelitian menunjukkan bahwa motivasi memiliki nilai koefisien regresi sebesar 0,547 dengan nilai signifikansi 0,0000 < a $(0,05)$, ini berarti variabel motivasi memiliki pengaruh positif signifikan pada minat investasi di pasar modal. Jadi hipotesis kedua diterima. Semakin tinggi motivasi yang dimiliki oleh mahasiswa, maka semakin tinggi pula minatnya untuk melakukan kegiatan investasi di pasar modal. Jika dibandingkan dengan variabel pemahaman investasi dan variabel bandwagon effect, variabel motivasi memiliki pengaruh yang paling besar terhadap minat investasi, terlihat dari nilai beta yang paling besar diantara dua variabel bebas lainnya. Ini berarti motivasi adalah faktor yang paling efektif bagi mahasiswa dalam rangka meningkatkan minat investasi di pasar modal. Menurut hasil jawaban responden, pernyataan pengaturan anggaran keuangan adalah indikator motivasi yang paling besar kontribusi pengaruhnya pada minat investasi di pasar modal. Saat melakukan pengaturan anggaran keuangan, mahasiswa akan dapat mengetahui berapa jumlah pemasukan dan pengeluaran perbulan. Ketika mahasiswa mengetahui bahwa jumlah pemasukan > jumlah pengeluaran, maka kelebihan dana akan menyebabkan timbulnya minat untuk mengambil tindakan investasi di pasar modal. Pengaturan anggaran keuangan juga dapat meningkatkan konsistensi mahasiswa untuk berinvestasi di pasar modal. Penelitian ini memiliki hasil yang konsisten dengan hasil penelitian sebelumnya oleh Riyadi (2017), Saputra (2018), Darmawan \& Japar (2020) yang menyatakan motivasi memiliki pengaruh positif pada minat investasi di pasar modal. Sesuai dengan teori hierarki kebutuhan, saat seseorang telah memenuhi kebutuhan substansialnya, selanjutnya ia akan termotivasi untuk memenuhi kebutuhan berikutnya, seperti kebutuhan berinvestasi. Bentuk motivasi tersebut berupa pencarian informasi tentang investasi, kemudian secara bertahap mulai mempraktikkannya.

$\mathrm{H}_{3}$ menyatakan bahwa bandwagon effect memiliki pengaruh positif pada minat investasi di pasar modal. Hasil penelitian menunjukkan bahwa bandwagon effect memiliki nilai koefisien regresi sebesar 0,216 dengan nilai signifikansi sebesar $0,010<a(0,05)$, ini berarti variabel bandwagon effect berpengaruh positif dan signifikan pada minat investasi di pasar modal. Jadi hipotesis ketiga diterima. Semakin tinggi fenomena bandwagon effect yang terjadi di lingkungan mahasiswa, maka akan semakin tinggi minat mahasiswa untuk melakukan kegiatan investasi di pasar modal. Berdasarkan pada hasil dari penelitian ini, berarti mahasiswa memiliki kecenderungan melakukan kegiatan investasi di pasar modal karena melihat orang disekitarnya seperti teman dan keluarga juga melakukan hal yang sama atau karena dorongan dari pihak lain seperti dosen, teman, ataupun keluarga. Namun, jika dibandingkan dengan variabel pemahaman investasi dan variabel motivasi, variabel bandwagon effect memiliki pengaruh yang paling rendah pada minat investasi di pasar modal, terlihat dari nilai beta yang paling kecil diantara dua variabel bebas lainnya. Jawaban kuesioner menunjukkan bahwa indikator bandwagon effect yang memiliki kontribusi pengaruh paling besar pada minat investasi di pasar modal adalah dorongan dari dosen. Hasil ini konsisten dengan hasil penelitian terdahulu oleh 
Hasanah et al. (2019), yaitu bandwagon effect terbukti berpengaruh pada minat investasi. Selain dalam hal suara mayoritas, bandwagon effect juga diartikan sebagai fenomena yang terjadi karena permintaan atau dorongan oleh seseorang, hal ini sesuai dengan pernyataan Le Bon (1895:33) yang menyatakan bahwa massa memiliki pendirian yang mudah goyah dan berubah. Sesuai dengan teori psikologi massa, seseorang akan cenderung beranggapan bahwa apapun yang dilakukan oleh orang kebanyakan di sekitarnya maka akan dianggap bagus, perihal kebenarannya akan ditimbang berdasarkan jumlah massa yang mengikutinya.

\section{SIMPULAN}

Berdasarkan hasil dan pembahasan tersebut, pemahaman investasi memiliki pengaruh positif pada minat investasi di pasar modal, motivasi memiliki pengaruh positif pada minat investasi di pasar modal, dan bandwagon effect memiliki pengaruh positif pada minat investasi di pasar modal.

Keterbatasan penelitian ini adalah hasil uji $\mathrm{R}^{2}$ yang tidak terlalu besar yaitu $60,9 \%$. Hal ini disebabkan karena adanya determinan lain yang dapat berpengaruh pada minat investasi mahasiswa di pasar modal, seperti kemampuan finansial dan persepsi risiko. Saran yang dapat peneliti sampaikan adalah agar peneliti selanjutnya menguji pengaruh variabel lain seperti kemampuan finansial dan persepsi risiko pada minat investasi di pasar modal, sehingga diketahui determinan yang mempunyai pengaruh besar pada minat investasi di pasar modal.

\section{REFERENSI}

Abdeldayem, M. M. (2016). Is There A Relationship Between Financial Literacy and Investment Decisions in The Kingdom of Bahrain. UCT Journal of Management and Accounting Studies, 4(2), 68-78. https://doi.org/10.24200/jmas.vol4iss02pp68-78

Adiguna, R. S. (2018). Kampanye 'Yuk Nabung Saham' IDX Untuk Mengubah Mindset Saving Society Menjadi Investing Society. Jurnal Komunikasi, 9(1), 93-99.

Agestina, N.I., Amin, M., Anwar, S. . (2020). Analisis Pengaruh Modal Minimal, Pemahaman Investasi, dan Teknologi Informasi Terhadap Minat Mahasiswa Berinvestasi di Pasar Modal Ditinjau dari Perspektif Ekonomi Islam. E-JRA, $9(1), 60-68$.

Ajzen, I. (1991). The Theory of Planned Behavior. Organizational Behavior and Human Decision Processes, 50, 179-211. https://doi.org/10.1016/07495978(91)90020-T

Awais, M., Laber, M.F., Rasheed, Nilofer., Khursheed, A. (2016). Impact of Financial Literacy and Investment Experience on Risk Tolerance and Investment Decisions: Empirical Evidence From Pakistan. International Journal of Economics and Financial Issues, 6(1), 73-79.

Banerji, Joyita., Kundu, Kaushik., Alam, P. A. (2020). Influencee of Behavioral Biases on Investment Behavior. SCMS Journal of Indian Management, 81-98.

Bisnis Bali. (2020). Di Tengah Corona, Jumlah Investor di Bursa Efek Bali 
Meningkat. Bisnis Bali.

Cherry, K. (2020). Bandwagon Effect as a Cognitive Bias. Verywellmind. https://www.verywellmind.com/what-is-the-bandwagon-effect-2795895

Darmawan, Akhmad and Japar, J. (2020). Investment Knowledge, Minimal Capital, Capital Market Training, and Motivation for Influence of Investment Interest in Sharia Capital Markets. International Journal of Islamic Economics $\mathcal{E}$ Business Management in Emerging Market (IJIEBMEM), 1(01), 110.

Gayatri. (2020). Teori Pasar Modal dan Investasi. AG Publishing.

Ghozali, I. (2016). Aplikasi Analisis Multivariate dengan Program IBM SPSS 2 (8th ed.). Badan Penerbit Universitas Diponegoro.

Gurusamy, P and Santhiyavani, S. (2019). A Study on Investor Perception Towards Investment in Capital Market With Special Reference To Coimbatore City. Cikitusi Journal For Multidisciplinary Research, 6(8), 72-84.

Hasanah, Afriyanti., Yulinda., Yuniasih, H. (2019). Analisis Pengaruh Bandwagon Effect dan Pengetahuan Investasi terhadap Minat Investasi Mahasiswa di Pasar Modal. Jurnal Bisnis Dan Kewirausahaan, 15(2), 101-107.

Hasibuan, M. S. P. (2016). Manajemen Sumber Daya Manusia (Edisi Revi). Bumi Aksara.

Hati, S. W. \& W. S. . (2019). Analisis Faktor-Faktor yang Mempengaruhi Minat Berinvestasi di Pasar Modal Bagi Generasi Milenial (Studi Pada Mahasiswi Jurusan Manajemen Bisnis Politeknik Negeri Batam). Journal of Business Administration, 3(2), 281-295.

Jannah, Waiqotul \& Utami, S. (2017). Analisis Fundamental, Suku Bunga, dan Overconfidence terhadap Pengambilan Keputusan Investasi pada Investor di Surabaya. Jurnal Bisnis Dan Manajemen, 1(2), 138-155. http://dx.doi.org/10.25139/ekt.v0i0.338

kontan.co.id. (2018). Riset Inside ID: Orang Indonesia lebih suka investasi emas ketimbang saham. Kontan.Co.Id. https://investasi.kontan.co.id/news/risetinside-id-orang-indonesia-lebih-suka-investasi-emas-ketimbang-saham

Kumar, S and Goyal, N. (2016). Evidence on Rationality and Behavioural Biases in Investment Decision Making. Qualitative Research in Financial Markets, 8(4), 270-287. https://doi.org/10.1108/QRFM-05-2016-0016

KumparanNews. (2017). 12,8\% Penduduk Malaysia Sudah Investasi Saham, di RI Baru 0,2\%. Diunduh Dari KumparanNews Website : https://kumparan.com/kumparannews/12-8-penduduk-malaysia-sudahinvestasi-saham-di-ri-baru-0-2

Le Bon, G. (1895). Crowd Psychology. G. Anagnostides Publications.

Lubis, P. K. . (2019). Influence of Knowledge Investment and Investment Motivation Against The Interest of Investing in The Stock Market on Economic Education Status of Students of State University of Medan. Journal of Physics: Conference Series, 1-5. https://doi.org/10.1088/17426596/1387/1/012064

Malik, A. . (2017). Analisa Faktor-Faktor Yang Mempengaruhi Minat Masyarakat Berinvestasi di Pasar Modal Syariah Melalui Bursa Galeri Investasi UISI. Jurnal Ekonomi Dan Bisnis Islam, 3(1), 61-84.

Maslow, A. H. (1943). A theory of human motivation. Psychological Review, 50(4), 
370-396. https://doi.org/10.1037/h0054346

Maulana, A.M., Kaukab, M. E. (2020). Apa yang Mempengaruhi Mahasiswa Berminat Investasi Saham? Jurnal Neraca, 16(1), 1-13.

Mudzakkir, A. (2019). Pengendalian Massa dalam Pemikiran Gustave Le Bon. Jurnal Kajian Ruang Sosial-Budaya. Jurnal Kajian Ruang Sosial-Budaya, 3(1), 65-78. https:/ / doi.org/10.21776/ub.sosiologi.jkrsb.2019.003.1.05

Nalini, R., Alamelu, R., Amudha, R., Motha, L. (2016). Financial Literacy and Its Contributing Factors in Investment Decisions Among Urban Populace. Indian Journal of Science and Technology, 9(27), 1-9. https://doi.org/10.17485/ijst/2016/v9i27/97616

Niesiobedzka, M. (2018). An Experimental Study of The Bandwagon Effect in Conspicuous Consumption. Current Issues in Personality Psychology, 6(1), 2633. https:// doi.org/10.5114/cipp.2017.67896

Nisa, Aminatun \& Zulaika, L. (2017). Pengaruh Pemahaman Investasi, Modal Minimal Investasi, dan Motivasi terhadap Minat Mahasiswa Berinvestasi di Pasar Modal. Jurnal PETA, 2(2), 22-35.

Riyadi, A. (2017). Analisis Faktor-Faktor yang Mempengaruhi Minat Mahasiswa Untuk Berinvestasi di Pasar Modal. Jurnal Ekonomi Dan Bisnis, 7(1), 23-41.

Sabir, S.A., Hisham, B.M., Hanita., B. K. . (2019). The Role of Overconfidence and Past Investment Experience in Herding Behaviour With A Moderating Effect Of Financial Literacy: Evidence From Pakistan Stock Exchange. Asian Economic and Financial Review, 9(4), 480-490. https://doi.org/10.18488/journal.aefr.2019.94.480.490

Saputra, D. (2018). Pengaruh Manfaat, Modal, Motivasi, dan Edukasi Terhadap Minat Berinvestasi di Pasar Modal (Studi pada Mahasiswa Sekolah Tinggi Ilmu Ekonomi Balikpapan). Future Jurnal Manajemen Dan Akuntansi, 5(2), 178-190.

Schunk, Dale H. and Dibenedetto, M. K. (2020). Motivation and Social Cognitive Theory. Contemporary Educational Psychology, 60, 1-10. https:// doi.org/10.1016/j.cedpsych.2019.101832

Simon, F. (2016). Consumer Adoption of No Junk Mail Sticker: An Extended Planned Behavior Model Assesing The Respective Role of Store Flyer Attachment and Perceived Intrusiveness. Journal of Retailing and Consumer Services, 29, 12-21. https://doi.org/10.1016/j.jretconser.2015.11.003

Stolwijk, S. B., Schuck, A. R. T., \& de Vreese, C. H. (2016). How Anxiety and Enthusiasm Help Explain the Bandwagon Effect. International Journal of Public Opinion Research, 29(4), edw018. https://doi.org/10.1093/ijpor/edw018

Sugiyono. (2017). Metode Penelitian Pendekatan Kuantitatif, Kualitatif, dan RAD. Alfabeta.

Tandio, Timothius \& Widanaputra, A. A. G. . (2016). Pengaruh Pelatihan Pasar Modal, Return, Persepsi Risiko, Gender, dan Kemajuan Teknologi pada Minat Investasi Mahasiswa. E-Jurnal Akuntansi Universitas Udayana, 16(3), 2316-2341.

tempo.co. (2020). Pandemi Corona, BEI: Jumlah Investor Saham Terus Meningkat. Diunduh Dari Tempo.Co Website. https://bisnis.tempo.co/read/1337780/pandemi-corona-bei-jumlah- 
investor-saham-terus-meningkat $/$ full\&view $=$ ok.

Wibowo, A. \& P. (2019). Pengaruh Pengetahuan Investasi, Kebijakan Modal Minimal Investasi, dan Pelatihan Pasar Modal Terhadap Minat Investasi (Studi Kasus Mahasiswa FE Unesa yang Terdaftar di Galeri Investasi FE Unesa). Jurnal Ilmu Manajemen, 7(1), 192-201.

Zakirullah \& Rahmawati, S. (2020). Faktor-Faktor Yang Berkontribusi Terhadap Perilaku Herding Pada Investor Saham Ritel di Bursa Efek Indonesia. Jurnal Ilmiah Mahasiswa Ekonomi Manajemen, 5(1), 1-23. 